\title{
414 ガラスの熱粘弾性の評価とモールドプレスシミュレーション
}

\section{Evaluation of Thermo-Viscoelastic Property of Glass and Numerical Simulation of Press Molding}

\author{
荒井 政大 (信州大) \\ 辰已正 和 (キヤノン (株)) \\ 加藤 佑 介 (信州大院)
松倉 利 顕 (チノンテック(株) $)$
}

Masahiro ARAI, Shinshu University, 4-17-1, Wakasato, Nagano City, Japan

Yuusuke KATOU, Graduate Student, Shinshu University

Masakazu TATSUMI, Canon Inc., 30-2, Shimomaruko 3-chome, Ohta-ku, Tokyo, Japan

Toshiaki MATSUKURA, CHINONTEC Industries, Inc., 4710, Nakasu, Suwa, Nagano, Japan

\begin{abstract}
In the present paper, numerical simulation about press-molding of glass lens is investigated. Since constitutive equation of glass depend on time-history and temperature, stress relaxation is observed on the glass subjected to applied loading, and these behaviors vary drastically depending on the temperature. In the present study, creep test has been conducted to determine the thermo-viscoelastic properties of glass. The creep function obtained by the experiment has been transformed into relaxation function employing Laplace transform. Shift factor which gives the relation between the time and temperature can be determined by creep test under several temperature. In the present analysis for press-molding of glass lens, history of the temperature and its distribution is computed by unsteady heat conduction analysis prior to the analysis of cooling sequence. The total FEM analysis for press-molding are executed taking into account the nonuniformly temperature distribution in the glass lens. Residual stresses under some processing conditions are estimated, and the optimal conditions of forming process are discussed in detail.
\end{abstract}

Key Words: Press Forming, Glass Lens, Finite Element Method, Thermo-Viselastic Theory, Relaxation Modulus, Creep Function, Laplace Transform, Residual Stress

\section{1. 緒 論}

近年の情報技術，光学技術の進歩によって，デジタルカメラ や光ディスクのピックアップなどをはじめとした光学デバィス の需要が増大している，それに伴い，光学素子の高精度化，生 産効率の向上, 生産コストの低減化が望まれている。従来, ガ ラス製デバイスの生産には直接研磨，化学研磨などが採用され ていたが，大量生産，非球面レンズなどの複雑な形状が求めら れているなかでガラスモールドプレスという成形方法が注目を 浴びている。しかしガラスは弾性と粘性をを有し，また㳑度にも 低仔する熱䉼弾性休であることから成形の最適条件を見積もる のが難しい(1).

著者らの研究グループでは、ガラスレンズのモールドプレス 成形に関し，熱䉼弾性理論に基づく数值シミュレーションを実 施し，成形プロセスの最適化を目的として種々の倹討を行って きた ${ }^{(3)}$. 今回の報告では, 冷却過程においてガラス内の非定常 熱伝導に伴う温度分布の時刻歴を考慮した解析を行い, 成形過 程終了後の残留応力に影響を及ぼす成形パラメータについて考 察を行った。

\section{2. 理 論}

$\mathbf{2 \cdot 1}$ 線形粘弾性体の構成方程式本研究では試料をク リープと応力緩和という2つの特徵的な現象を有する線形䉼 弾性休として取り扱う。線形粘弾性休に任意の応力を作用させ たとき，生じるひずみを計算する際，重悋合わせの原理を用 いることができる，任意の応力に対するひずみの時間变動は Duhamel の積分形 (式 (1)) で示され, 緩和弾性:係数の概念か ら式 (2) が同様に示される。

$$
\begin{array}{ll}
\varepsilon(t)=\int_{0}^{t} J(t-\tau) \frac{d \sigma(\tau)}{d \tau} d \tau+\sigma\left(0^{+}\right) J(t) & (t \geq 0) \\
\sigma(t)=\int_{0}^{t} E(t-\tau) \frac{d \varepsilon(\tau)}{d \tau} d \tau+\varepsilon\left(0^{+}\right) E(t) & (t \geq 0)
\end{array}
$$

ここで, $J(t)$ はクリープ関数であり, 時間 $t=0$ から単位ス テップ状の応力を入力した時のひずみの時間変動を表す． $E(t)$ は緩和弾吽係数であり，時間 $t=0$ から単位ステップ状のひず みを人力した時の応力の時間変動を表す.

式 (1), 式 (2)に Laplace 変換を適用して整理するとLaplace 像空間上におけるクリープ関数と緩和弾性係数について以下の 関係が成り立つ。

$$
\bar{E}(s)=\frac{1}{s^{2} \bar{J}(s)}
$$

ここで，上付き添字 ‘’は，各物理量の Laplace 変換を表す. また, $s$ は Laplace 変換パラメータである.

なお，本研究における計算では，大変形時の体積変化は微小 であるものとする。すなわち，休積弾吽率 $K(t)$ は緩和挙動を 示さないものとし，以下のようにヤング率とポアソン比の瞬間 弾性率を用いて表す(4)

$$
K(t)=K_{0}=\frac{E_{0}}{3\left(1-2 \nu_{0}\right)}, \quad(t \geq 0)
$$

上式を Laplace 変換することによって，体積弾性率の Laplace 変換 $\bar{K}(s)$ が以下のように求められる.

$$
\bar{K}(s)=\frac{1}{s} \frac{E_{0}}{3\left(1-2 \nu_{0}\right)}
$$


緩和せん断弾性係数 $\bar{G}(s)$ は, 緩和弾性係数 $\bar{E}(s)$ および体 積弾性率 $\bar{K}(s)$ により次式により与えられる。

$$
\bar{G}(s)=\frac{3 \bar{K}(s) \bar{E}(s)}{9 \bar{K}(s)-\bar{E}(s)}
$$

式 (3), (5), (6) より, 実験により求めたクリープ関数と休 積弾性率から, Laplace 像空間上における緩和せん断弾性係数 が算出可能であり, 細野の方法を用いて数值 Laplace 逆変換す ることにより，実時間における緩和せん断弾性係数が求まる.

\section{3. 数值シミュレーション}

$3 \cdot 1$ マスターカーブ, シフトファクター＼cjkstart基準温度にお ける緩和弾性係数を固定し，それ以外の各温度の緩和弾性係 数を対数軸上で平行移動させ一本の曲線に重ねたものをマス ターカーブという。 またその平行移動量よりシフトファクター を求めることができる。つまり熱粘弾性特性はマスターカー ブとシフトファクターを求めることで表すことができる。本 研究では，シフトファクターの近似に以下の式 (7) に示される Narayanaswamy の式を用いた ${ }^{(2)}$. 実際の FEM 解析では活性: 化エネルギー $\Delta H$ 在計算条件として与えている。

$$
\ln \alpha_{T_{0}}(T)=\frac{\Delta H}{R}\left(\frac{1}{T_{0}}-\frac{1}{T}\right)
$$

$\Delta H[\mathrm{~kJ} / \mathrm{mol}]$ は活性:化エネルギー, $R[\mathrm{~kJ} / \mathrm{mol} ・ \mathrm{~K}]$ は理想気 体の気休定数, $T_{0}[\mathrm{~K}]$ は基準温度, $T[\mathrm{~K}]$ は温度とする.

3.2 Maxwellモデルによる近似 Maxwell モデルとは, バネとダッシュポットを直列につないだものを並列に連結した もので，粘弾性特性を表す力学モデルの1つである。このモデ ルを用いてマスターカーブを近似し，解析に用いる， $G(\infty)$ を 考慮した $\mathrm{n}$ 要素の Maxwell モデルにおいて緩和せん断弾性係 数は，以下の式で示される.

$$
G(t)=\sum_{i=1}^{n} G_{i} \exp \left(\frac{-t}{\lambda_{i}}\right)+G(\infty)
$$

ここで，式 (8) 中の $n$ は 3 ，として，木知数である $G_{i}, \lambda_{i}$ を 探索により決定した。

$3 \cdot 3$ 有限要素法によるレンズプレス成形解析 本研究で はFig.1 で示されるような球面レンズの成形シミュレーション の結果について示す。解析には沨用有限要素法コードANSYS ver.10.0を用いた。解析モデルには二次元軸対称モデルを用い， 解析に用いるガラス材は TaF3 材とした。温度条件と圧力条件 は Fig. 2 に示す.

本解析では，冷却過程における伝熱解析を実施することによ りレンズ内の温度分布を考虑した，ただし，温度条件は，金型 およびガラス忉外周部に Fig. 2 に示される温度条件を与え伝熱 解析を実施し，その温度デー夕を構造解析に用いることにより 実施した。また，冷却時間に関して，成形温度からガラス転移 点までの冷却時間 $t_{1}$, ガラス転移点以下の冷却時間 $t_{2}$ として 冷却時間を 2 段階に变化させ, $t_{1}=10, t_{2}=150,300,600$ の 3 通りについて解析を実施した。

Fig.3,Fig.4,Fig.5 にそれぞれの成形過程終了後の残留応力の 分布図を示す．冷却時間 $t_{2}$ を長く寸ることにより残留応力の分 布に变化はみられないが, 残留応力の最大值が小さくなること がわかる。これより，冷却過程において発生するレンズ内部と 外部の温度差が残留応力に影響を与えることが明らかになった。

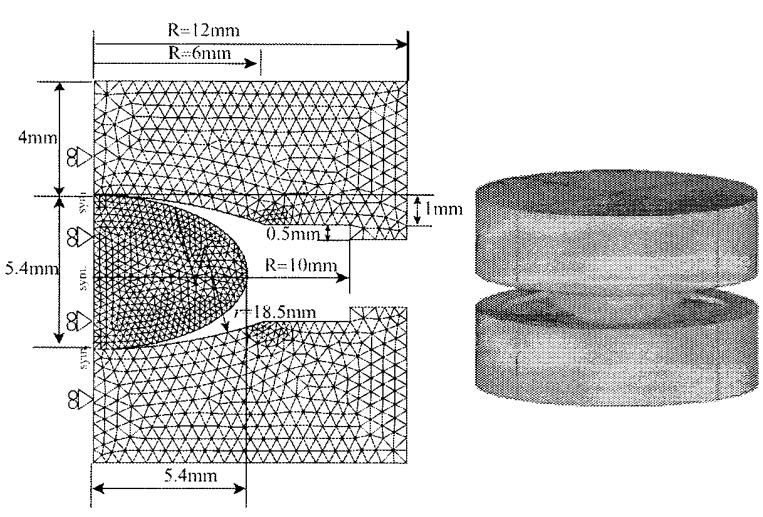

Fig.1 FEM model (spherical lens ; $\mathrm{R}=18.5[\mathrm{~mm}]$ )

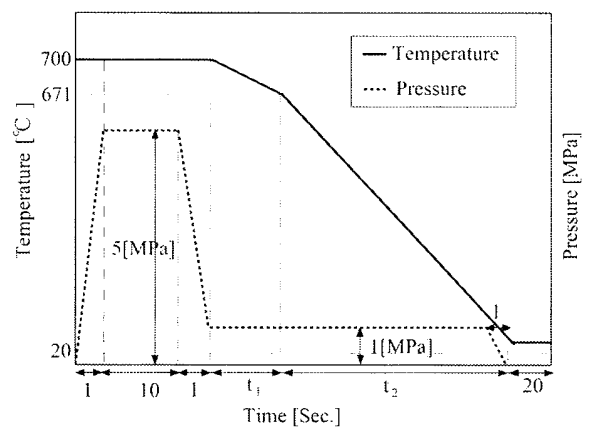

Fig.2 Pressure and temperature condition.

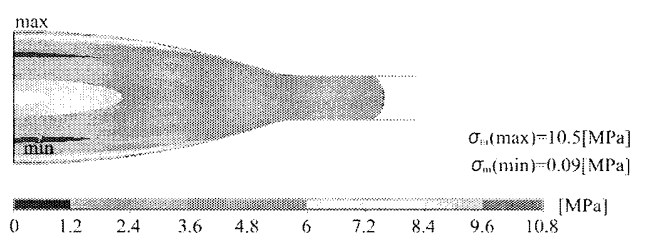

Fig.3 Residual stress (von Mises) $\left(t_{1}=10[\mathrm{~s}], t_{2}=150[\mathrm{~s}]\right)$.

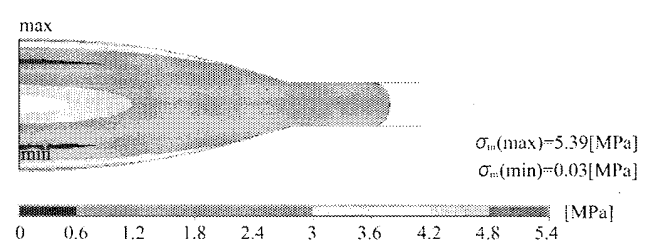

Fig.4 Residual stress (von Mises) $\left(t_{1}=10[\mathrm{~s}], t_{2}=300[\mathrm{~s}]\right)$.

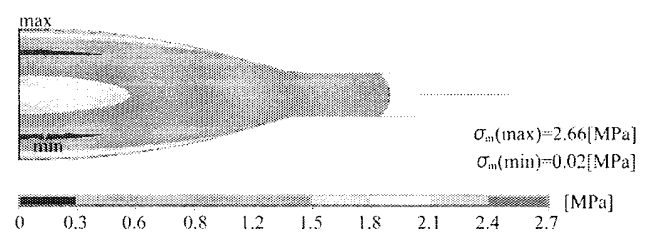

Fig.5 Residual stress (von Mises) $\left(t_{1}=10[\mathrm{~s}], t_{2}=600[\mathrm{~s}]\right)$.

\section{文献}

（1）例えば,クリュチニコフ他，下野英替訳，ガラスの科学，科受晢及新書， (1972), 来宗闵菁.

(2) Narayanaswamy, O. S., A Model of Structural Relaxation in Glass, Journal of the American Ceramic Society, Vol.54, No.10, (1971), pp.491-498.

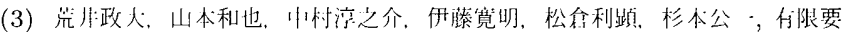
素法によるガラスレンズのブレス成形シミュレーション. 機論 (A), Vol.72, No.717, (2006), pp.683-690.

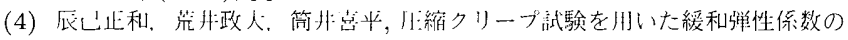

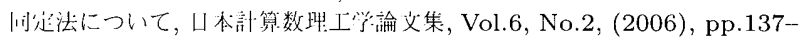
142 . 